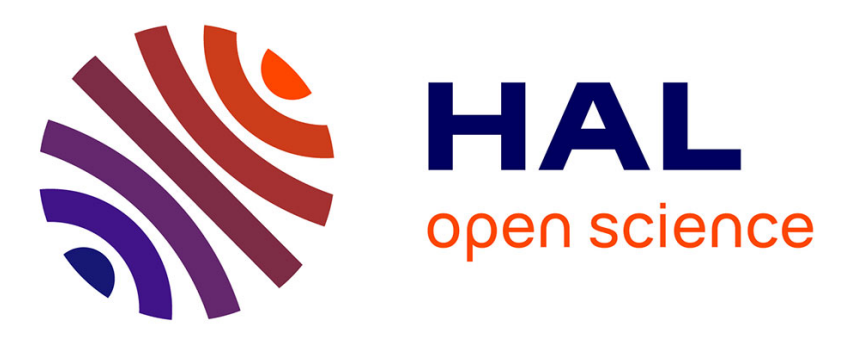

\title{
Roots and patterns in Beja (Cushitic): the issue of language contact with Arabic
}

Martine Vanhove

\section{To cite this version:}

Martine Vanhove. Roots and patterns in Beja (Cushitic): the issue of language contact with Arabic. Thomas Stolz, Martine Vanhove, Hitomi Otsuka \& Aina Urdze. Morphologies in contact, Akademie Verlag, pp.323-338, 2011. halshs-00651067

\section{HAL Id: halshs-00651067 https://shs.hal.science/halshs-00651067}

Submitted on 12 Dec 2011

HAL is a multi-disciplinary open access archive for the deposit and dissemination of scientific research documents, whether they are published or not. The documents may come from teaching and research institutions in France or abroad, or from public or private research centers.
L'archive ouverte pluridisciplinaire HAL, est destinée au dépôt et à la diffusion de documents scientifiques de niveau recherche, publiés ou non, émanant des établissements d'enseignement et de recherche français ou étrangers, des laboratoires publics ou privés. 


\title{
Roots and patterns in Beja (Cushitic): The issue of language contact with Arabic
}

\begin{abstract}
:
A large part of the morphology of Beja, the sole language of the Northern branch of Cushitic (Afroasiatic), belongs to the root and pattern system. This system is typologically similar to the Semitic one (particularly robust in Arabic) and is also found to a lesser extent in two neighboring Cushitic languages, Afar and Saho, but not in any other Cushitic language. This paper reviews the different patterns of the Beja morphological system, and compares them with the systems of its main Semitic contact language (Arabic) and with other Cushitic languages (Afar and Saho). No clear case of borrowing, copying, or replication from dominant and prestigious Arabic could be found, but sociolinguistic and linguistic data favors an interpretation in terms of a convergence phenomenon. The paper argues that contact with Arabic was a strong factor for the preservation of a crosslinguistically uncommon system in a large part of the Beja morphology. It also argues that intensive language contact between genetically related languages may help to preserve a morphological system which otherwise would have disappeared as is the case in most other Cushitic languages.
\end{abstract}

\section{Introduction}

FERGUSON (1970 \& 1976) studied a series of linguistic features (phonetic, morphological, syntactic and lexical) in Semitic, Cushitic and Omotic languages to establish the so-called Ethiopian language area (a misleading label since it concerns Ethiopia, Eritrea, Somalia, Northern Kenya and Eastern Sudan; Zaborski [2003] proposed instead the term 'North-East African Language Macro-Area'). Among others, TosCO (2000) reviewed all these features and questioned their choice and the validity of the isogloss bundles. He concluded on the non-existence of an Ethiopian language area and that unilateral contact is the rule in this zone, somehow following the lines developed in Leslau (1945, 1952 \& 1959) and Moreno (1948) about the influence of Cushitic languages upon Semitic languages of the area. But as summarized in CRASS \& MEYER

Four recent papers, namely Bender (2003), Crass (2002), Crass and Bisang (2004), and Zaborski (2003) favor the existence of a linguistic area. Bender (2003) argues against Tosco (2000b) and tries to extend the ELA [Ethiopian Language Area] by testing a number of Nilo-Saharan languages [also present in this zone] using a selection of Ferguson's features. Crass (2002) discusses two phonological 
features in detail; in Crass and Bisang (2004) the discussion is extended to features such as word order, converbs, and ideophones verbalized by the verb 'to say'. Zaborski presents the most extended list, including twenty-eight features which he considers to be valid for a macro-area including Ethiopia, Eritrea, Djibouti, Somalia, and parts of Sudan, Kenya, and even Tanzania and Uganda. (CRASS \& MEYER 2007: 230)

A further study by Simeone-Senelle \& VAnHove (2006), enlarged to the Red Sea area, claimed that in North-Eastern Africa, influences between Cushitic and Semitic languages were to some extent bidirectional, on the basis of some additional features hardly ever taken into consideration in the previous literature. They showed possible cases of Semitic influence on Cushitic, such as the absence of labiovelars, the position of the head $v s$ the relative clause, or the root and pattern morphological system, which will be the bulk of this paper. However, their study concluded that mutual influences probably do not reflect a long term bilateral symmetric contact situation, a process which is sometimes included in the characterization of a Sprachbund (see e.g. THOMASON \& KAUFMANN 1988). These influences could "mirror successive stages due to the changing sociolinguistic situations and levels of bi-[lingualism] or multi-lingualism, as well as to the prestigious role of Arabic for religious, economic and political reasons" (SIMEONE-SENELLE \& VANHOVE 2006: 62), as is specially the case for Beja.

On the other hand, SASSE (1986) and ZABORSKI (1991), who were also critical of Ferguson's approach, considered that linguistic factors do not exclude the possibility of smaller linguistic areas in the zone, such as an Eritrean-North Ethiopian area (Zaborski) or a Southwest Ethiopian area (Sasse). This paper is also an attempt to suggest that the Eastern SudanEritrea zone could be another one of these smaller linguistic sub-areas. Moreover, on the basis of several Afro-Semitic and East-Cushitic languages spoken in the Highland East Cushitic/Gurage subarea of Ethiopia, CRASS \& MEYER (2007) themselves proposed a new series of morphological and syntactic features to identify this linguistic subarea, and consider that they could be possible candidates for establishing the existence of a North-East African language macro-area.

Given the particular socio-linguistic context in which Beja has evolved (see section 2 below), the aim of this paper is to try and show that language contact may lead to the preservation of typologically rare and endangered morphological strategies, namely the root and pattern schema. 


\section{The Beja language: classification and sociolinguistics}

Beja (named bedawije-t by the Beja people) is an unwritten language, traditionally classified as the sole member of the Northern branch of Cushitic of the Afroasiatic phylum. It is mainly spoken in the Red Sea Hills in Eastern Sudan by approximately 1,100,000 speakers, as well as by a much smaller number of speakers in Northern Eritrea and Southern Egypt (where it is endangered).

Beja society is organized into clans and tribes, and its islamisation began as early as the tenth century. All Bejas are now Muslims. Until the first half of the $20^{\text {th }}$ century, their main occupations were camel trading and pastoralism; only the latter survives today to a lesser extent since the terrible droughts of the mid-1980s. Throughout their history, Bejas have had intensive contacts with Tigré (South-Semitic), Nubian (Nilo-Saharan), and Arabic (Central Semitic) speakers and today, in Sudan, most Beja males are bilingual with Sudanese colloquial Arabic. Bilingualism is less frequent among women. Only a minority of the Bejas have knowledge of Tigré, but a few clans at the border with Eritrea have switched to Tigré (with some influence from Beja). In Sudan, although the illiteracy rate is still high, formal education is increasing among young villagers and city dwellers, but girls still seldom go further than primary level. The sole language of education is Classical Arabic, with a mixture of colloquial Sudanese Arabic. In addition Quranic Arabic is taught in Quranic schools to young boys and girls alike.

\section{Roots and patterns in the North-East Africa Macro-area}

Within the Afroasiatic phylum, the Semitic and Berber stocks (the latter to a different extent) are renowned for having a conspicuous and robust consonantal root system and a morphological system which is not predominantly organized in a concatenative way ${ }^{1}$ but on the basis of patterns which determine semantic and functional classes of words. Patterns constitute a closed inventory consisting of qualitative or quantitative vocalic alternation in the stem, syllabic structure changes, and different types of reduplication, to which affixes can also be added. Below is a well-known example from Arabic.

(1) Roots and patterns in Arabic

Root $K T B>K a T a B a$ 'to write', $K a T T a B a$ 'to write a lot' mi-KTu:B 'written', Ka:TiB 'writer', KiTa:B 'book', KuTuB 'books', etc.

This root and pattern morphological structure also exists in some languages of North-East Africa. In the South-Semitic branch to which most of the Semitic languages of this area belong, as well as in Arabic,

\footnotetext{
${ }^{1}$ Suffixed and prefixed morphemes do exist also in Semitic and Berber languages.
} 
the structure of the lexicon, for both verbs and nouns, is organized along these lines. But whereas this is true for the South-Semitic languages spoken in the northern part of the area, such as Tigré (RAZ 1983) with which some varieties of Beja are in contact, in the South-Semitic languages spoken further South, the root and pattern morphological system is archaic, as in Amharic for instance (LESLAU 2000: 40), and sometimes very marginal as in Gurage (HETZRON 1977: 53).

TOSCO (2000: 344) considered that in this area the root and pattern schema is 'Semitic-biased', i.e. almost exclusively limited to the Semitic languages. But this morphological structure is to a lesser degree also characteristic of the three Cushitic languages of the northern part of North-East Africa, Beja, Afar and Saho (which belong to the Eastern branch of Cushitic), as opposed to the other Cushitic languages spoken in the rest the area, where stems are usually invariable and the root and pattern schema at best highly marginal, and most often absent (cf. COHEN 1988: 256).

Following Sasse and Zaborski's argumentation about smaller subareas, this paper claims that the preservation of the root and pattern schema, although genetic, could be an areal feature differentiating the extreme northern part of the North-East African zone from the rest of the Cushitic languages of the area.

The following sections provide a general overview of the root and pattern schemas in Beja, with some limited comparisons (for lack of space) with Arabic, Afar and Saho.

\section{Roots and patterns in Beja}

In Beja the root and pattern morphological system concerns a sizeable portion of the lexicon: a large part of the verbal morphology (conjugations, verbal derivations, verb-noun derivations), and part of the nominal morphology (adjectives, nouns, 'broken' plurals, and to a lesser extent place and instrument names).

\subsection{Verb morphology}

\subsubsection{Verb classes}

There are two different verb classes in Beja.

The first class (V1) is made of an invariable stem conjugated with suffixes for all TAMs. Historically, this is the most recent type which in most other Cushitic languages became the sole conjugation system. This verb class is not concerned by the root and pattern schema. 
The second verb class (V2) is made of a stem with ablaut which varies according to $\mathrm{TAM}^{2}$, person and number, to which prefixed personal indexes for all TAMs are added. This is diachronically the oldest pattern which survives only in a few Cushitic languages. In Beja this verb class contains the majority of the verbs and they form up to $60 \%$ of the total number of verbs, as against approximately $30 \%$ in Afar and Saho, and only five verbs in Somali and South Agaw (COHEN 1988: 256). Thus the hypothesis is that contact with Arabic (and possibly also with AfroSemitic Tigré in Eritrea, but further study is needed) helped to preserve this verb class in the Cushitic languages of the zone. Below is an example of the two basic conjugations (Perfective and Imperfective) for biconsonantal and tri-consonantal roots:

\begin{tabular}{lll}
\hline & Bi-consonantal $D F$ 'go'3 & Tri-consonantal $K T M$ 'arrive' \\
\hline PFV & i-dif'he went' & $i$-ktim 'he arrived' \\
& $i$-dif-na 'they went' & $i$-ktim-na 'they arrived' \\
IPFV & $i$-n-diff'he goes' & $k<$ an $>$ ti:m 'he arrives' \\
& ei-dif-na 'they go' & e'-katim-na 'they arrive' \\
\hline
\end{tabular}

Table 1: Perfective \& Imperfective patterns

Prefix conjugations are used in Arabic and South-Semitic languages but their functions and origin are different from Beja. In the Semitic languages the prefix conjugation has an aspectual value of Imperfective while in Cushitic it marks a particular morphological class of verbs. As for their respective origins, the Cushitic prefix conjugation (in the singular) originates in a periphrastic verbal construction with an auxiliary verb meaning 'say, be', while the prefix conjugation of Semitic has various origins, depending on the branches, none of them including a verb ‘say' or 'be' (see e.g. COHEN 1984). The grammaticalization pattern of Cushitic occurred also later on for all the personal indexes of the suffix conjugation (COHEN 1969-70 \& 1984). Although different grammaticalization processes were used in the two branches of Afroasiatic, all this suggests that the root and pattern system might have already been very robust in Beja (and possibly also in proto-Cushitic) at an ancient stage of the language ${ }^{4}$, which is unfortunately impossible to date for lack of old documents. It is noteworthy that there are at least traces of vocalic alternation between the Perfective and the Imperfective in all the

2 For details about vocalic alternation in Cushitic and Afroasiatic see CoHEN (1974 \& 1984).

3 All examples are taken from the lexicon in Roper (1928). His transcription has been changed into IPA (except for geminated consonants which are doubled instead of using the semi-colon).

4 CoHen (1984: 94) states (without mentioning on which study his statement is based) that tri-consonantal verbs with prefixed paradigms are often of Semitic origin. 
branches of Cushitic (see COHEN 1984: 88-102), thus reinforcing the hypothesis of an ancient root and pattern schema in Cushitic.

\subsubsection{Converbs}

Among the four non-finite Beja verb forms, only one converb, the negative simultaneous converb, belongs to the root and pattern schema (the others are built with suffixes added to the stem of the Imperative form). It consists of the negative particle $b a:=$, proclitic to a variable stem (with ablaut). Nothing similar exist in Arabic, Afar or Saho.

(2) Negative simultaneous converb ${ }^{5}$

gid 'throw' > gid-er, neg. bai=gird 'while I/you/he... was not throwing'

kitim 'arrive' > kitim-e', neg. bar =kati:m 'while I/you/he... was not arriving'

Similar stems do not have the same function in Arabic, and they do not exist in Afar and Saho.

\subsubsection{Verb derivation}

Beja is the only Cushitic language that uses qualitative ablaut in the stem as a derivational device, for the expression of various semantic and voice derivation. The ablaut may be combined with reduplication of one syllable or the use of prefixes. Below is an overview of the six basic verbal derivation patterns in Beja for V2:

\begin{tabular}{lll}
\hline INT & bis 'bury'> bo's & kitim 'arrive' > ka:tim \\
FREQ & bis 'bury' > ba:bis, ba:babis & kitim 'arrive' > ka:tatim \\
REFL & fif'pour' > faf & rimid 'avenge' > rimad \\
PASS & min 'shave' > a:to'-ma:n & dibil 'collect' > at-daba:l \\
CAUS & dir 'kill' > so:-dir & kitim 'arrive' > si-katim \\
RECP & gid 'throw' > amo:-ga:d & girim 'be inimical' > am-gara:m \\
\hline
\end{tabular}

Table 2: Verb derivation patterns

Each of these patterns is discussed in turn in what follows.

\subsubsection{Intensive}

\begin{tabular}{|c|c|c|}
\hline $\begin{array}{l}\text { bis 'bury’ > bo:s } \\
\text { 'bury repeatedly' }\end{array}$ & $\begin{array}{l}\text { dir 'kill' > dair } \\
\text { 'slaughter' }\end{array}$ & $\begin{array}{l}\text { kitim 'arrive' > ka:tim } \\
\text { 'arrive repeatedly at the } \\
\text { same place' }\end{array}$ \\
\hline
\end{tabular}

The intensive pattern of Beja V2 consists of a qualitative and quantitative vocalic alternation, usually $o$ : for bi-consonantal verbs, with

5 The citation form of Beja verbs used throughout this paper is the stem of the imperative form devoid of its inflectional morphemes, as in Roper (1928). 
a few exceptions (such as dir 'kill' above), and ar in the first syllable of tri-consonantal verbs.

Among the Semitic languages of North-East Africa and the Arabian Peninsula, this ablaut pattern for intensive derivation is only known in the modern South Arabian (MSA) languages (South-Semitic) spoken in Eastern Yemen. (It is also used for causative and transitivisation). The MSA languages are direct cognates of the South-Semitic languages of North-East Africa and it is usually admitted that South Semitic languages of Africa were imported by South-Arabian speakers (Ullendorf 1955). Still this ablaut pattern was not retained in the South-Semitic languages of North-East Africa. It is also unknown in Arabic with an intensive value, a semantic derivation which is made through the reduplication of the second consonant of the root. The Arabic derived form with $a:$ in the first syllable has a goal, or sometimes reciprocal, meaning.

\subsubsection{Frequentative}

FREQ bis 'bury' > ba:bis, ba:babis
'bury in several graves'

The frequentative derivation pattern, which is generally used for transitive verbs with plural objects, consists for bi-consonantal verbs in the reduplication of the unique syllable + a qualitative and quantitative ablaut, and for tri-consonantal verbs in the reduplication of the beginning of the second syllable + a qualitative and quantitative ablaut.

The semantics, the syntax and the forms are specific to Beja. They are unknown to other Cushitic or Semitic languages, although the reduplication pattern (without ablaut) is widespread in Cushitic and South-Semitic. Syllabic reduplication does not occur in Arabic.

\subsubsection{Reflexive}

REFL fif'pour' > faf'boil over, overrun'

rimid 'avenge' > rimad'avenge oneself'

Beja is the sole Cushitic language to differentiate between active and reflexive voice by means of vocalic alternation. The reflexive voice has a characteristic short $a$ in the Perfective (in the second syllable in triconsonantal verbs) as opposed to $i$ for the active base form.

Remnants of this pattern exist in some Semitic languages, among them Arabic, but in a fossilized form. It is worth mentioning that the Imperfective form of the reflexive voice in Beja attests the presence of a productive and historically more recent device in Semitic, very much alive in Arabic, i.e. the shared innovation of a prefix $t$ - added to the stem in Beja: a-t-rami:d 'I avenge myself'. In Arabic, the $t$ is infixed after the first root consonant for the basic stem or prefixed to two derived stems. 
The $t$ characteristic of the reflexive is unknown in other Cushitic languages.

\subsubsection{Passive/middle}

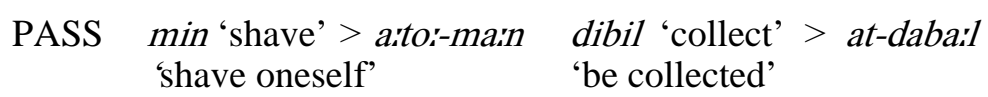

In Cushitic, qualitative ablaut for the passive/middle voice only occurs in Beja. It is characterized by a long vowel $a$ : (in the second syllable for tri-consonantal verbs, in addition to an ablaut to $a$ in the first syllable) in the Perfective. In addition, a prefix with a dental consonant $-t$-, whose form depends on the syllabic structure of the verb, is added to the passive/middle stem. This pattern is also used with recent borrowings from Arabic: kitib 'write', at-kata:b 'be written'.

In classical Arabic there is also a qualitative ablaut for the expression of the passive voice, but this is unknown in colloquial Arabic varieties (or at best fossilized in some varieties of the Arabian Peninsula). This pattern does not include the addition of a prefix. In Arabic, the passive/reflexive form is now made via a $t$ prefixed to or infixed in the stem, or via a prefix $n$-, depending on the stem of the base and derived forms, or by a combination of both consonants in some colloquial varieties.

In South-Semitic of North-East Africa, ablaut is not used for voice.

\subsubsection{Causative}
CAUS dir 'kill’ > so'-dir 'make kill' kitim 'arrive' > si-katim 'make arrive’

Although an -s suffix (not a prefix as in Beja) is common in Cushitic, Beja is once more the only Cushitic language which uses ablaut for the causative derived form; it is attested in both Perfective and Imperfective for tri-consonantal verbs, but only in the Imperfective for bi-consonantal verbs. They are characterized by a short $a$ in the first syllable of triconsonantal roots. The prefix with an $s$, whose vowel quality depends on the syllabic structure of the verb, is added to the stem.

Neither the qualitative ablaut nor the $s$ prefix exist in Arabic ( $s$ - occurs in other Semitic languages of the Near East like Aramaic). The prefix $s$ only occurs in Arabic in combination with $t$ with mostly a reflexive/ middle sense (of the derived form with a prefix Pa-) and a denominative sense. Arabic has two causative forms: the same as the intensive one, i.e. with a geminated second root consonant, and the Pa-C1C2aC3a pattern.

\subsubsection{Reciprocal}

RECP gid 'throw' > amo'-gard girim 'be inimical' > am-gara:m 'throw at each other' 'be inimical to each other' 
Like the passive/middle voice, the reciprocal is characterized by a qualitative ablaut in $a:$ in the stem (in the second syllable for triconsonantal verbs), but the prefix is different and consists of am- $(+\mathrm{a}$ long vowel - $o$ : for monosyllabic verbs).

This $m$ is not used for verbal derivation in Arabic (but $m$ is used to build passive participles - and active ones). Arabic, marginally though, uses a quantitative ablaut of the first vowel of the stem to a: to express, marginally, the reciprocal of the base form. But most often the reciprocal meaning is expressed by means of the more specifically reflexive forms with the $t$ - prefixed or infixed to the derived form in $a$ : in the first syllable or to the base form.

In some other Cushitic languages $m$ is used as a suffix for a passive/ middle voice (without ablaut in the stem). In Beja $m$ can also marginally be used as a passive marker, together with ablaut, for a few transitive intensive verbs such as ame:-saj 'be flayed', amer-bidan 'be forgotten'.

\subsection{Verb-noun derivation}

As with the verbal morphology, the root and pattern morphology only concerns the largest verb class V2, i.e. the one conjugated with prefixes. This morphological structure is limited to two of the three verb-noun forms of Beja: nomen actionis (or masdar) and agent noun (the third one, the so-called 'gerund' is built with a suffix $-a$ added to the stem of the imperative).

\subsubsection{Nomen Actionis / masdar}

For the base forms of old verb class V2, masdars are generally, and freely, formed through a qualitative ablaut, most often to $u$ ' (in the second syllable for tri-consonantal roots), sometimes $a$ : for bi-consonantal roots or defective verbs:

(3) Masdars of base forms of V2

kitim 'arrive' > kitu:m 'arrival'

SPif 'cough' > SPu:f 'coughing'

bir' 'snatch' > bair' act of snatching'

riwi 'arrest, cause to stop' > ra:wa: 'halting, ceasing'

A $\mathrm{C} 1 \mathrm{aC} 2 \mathrm{u}: \mathrm{C} 3$ pattern with a characteristic second vowel $u$ : (and a different vowel than in Beja in the first syllable) is a masdar pattern in classical Arabic, but it is semantically limited almost exclusively to verbs expressing movements and positions of the body (see BLACHÈRE \& GAUDEFROY-DEMOMBYNES 1975: 81).

In Afar and Saho, the masdars of the prefix verb class are regularly characterized by a long or short vowel $a(:)$ (not $u$ :) alternating with the vowel(s) of the verb stem (see SimeOnE-SENELle \& VANHOVE 2006: 43). 
In Beja, the vowel $a$ is also characteristic of the stem of masdars for a few bi-consonantal and defective verbs, which in addition have a prefix $m V$ - (the list below is probably exhaustive):

(4) Masdars of a few bi-consonantal and defective V2

dir 'kill' > ma-dar 'murder, killing', ma-do:r 'murder(ous)'

Pamit 'grasp' > ma-Pmat 'act of grasping'

hiw 'give' > mi-jaw 'gift, act of giving'

$a h$ 'take' > mi'-jaj 'receipt, act of receiving or taking'

jiwid 'dress the hair by curling and frizzing' > mi--Wad 'curl'

$d i$ 'say' > mir-jad' 'act of saying'

firi 'give birth' > mi-fre:j 'birth'

$r i k^{w} i$ 'be afraid' > mi-rk' $k^{w}$ ' 'fear'

For another handful of masdars with the prefix $m V$-, there is no ablaut on the stem, just a syllabic change for tri-consonantal roots:

(5) Masdars without ablaut of V2

dha 'be fat' > ma-dha 'fatness'

dhan 'live' > mi-dhan 'life, health'

$g^{w}$ imid 'lengthen' > mu'-gmid 'length'

$r^{\prime \prime}{ }^{w} u k$ 'thick' > mi-rk' $u k$ 'thickness'

The absence of ablaut is also the case for the few masdars of the derived reflexive forms:

(6) Masdars without ablaut of Reflexive V2

REFL: lag 'dance' > ma-lag 'dancing'

In Arabic, one class of (tri-consonantal) verbs, those with $a$ or $u$ in the Imperfective, and most of the derived verbs with $a$ : and a goal meaning, form their masdars with a prefix ma-.

The masdars of three other derived forms (causative, reciprocal and passive/middle), are all characterized by a suffix -o:j, added to the derived or to the basic forms of the verb.

(7) Masdars of derived V2

CAUS: sor-dir-o:j 'act of murdering'; si-katm-o:j 'act of making arrive'

PASS: ato'-min-o:j 'act of being shaved'; at-Pabk-o:j 'act of being caught'

RECP: am-garim-o:j 'mutual enemity'

The other two remaining verb forms have no masdar or share it with the base form.

Although two patterns are common to some extent with Arabic, the Beja system is different in its general organization. 


\subsubsection{Agent Nouns}

Agent nouns combine qualitative ablaut and the suffixation of a morpheme, -a:na, the same suffix as the one used to form agent nouns for V1 verbs (for some tri-consonantal roots a suffix $-i$ is added instead of -a:na). For disyllabic agent nouns, the stem is in fact that of the derived intensive verb form.

(8) Agent nouns of V2

$$
\begin{aligned}
& \text { bir 'snatch' > bo:r-a:na 'snatcher' } \\
& \text { gid 'throw' > ge:d-a:na 'thrower, a good shot' } \\
& \text { bis 'bury' > bo:s-a:na 'burier' } \\
& \text { min 'shave' > mo:n-a:na 'barber' } \\
& \text { tu:l 'point with the finger' > tu:l-a:na 'index' } \\
& \text { kitim 'arrive' > ka:tm-a:na / ka:tim-i 'newcomer' }
\end{aligned}
$$

The Beja agent noun pattern for tri-consonantal roots is reminiscent of the active participle of the base form of Arabic verbs (but no suffix is added in Arabic), which can also have a value of agent noun.

\subsection{Noun morphology}

\subsubsection{Adjectives}

Beja has seven different patterns which are used to derive adjectives

\begin{tabular}{|c|c|c|}
\hline Pattern & Adjective & Verb form \\
\hline $\mathrm{aCla} C 2$ & $\begin{array}{l}\text { ama:g 'bad' } \\
\text { ata:b 'full' }\end{array}$ & $\begin{array}{l}\text { mig 'do evil' } \\
\text { tib'fill' }\end{array}$ \\
\hline $\mathrm{C} 1 \mathrm{aC} 2 \mathrm{a}$ & mar?a 'wide' & mir? 'be wide' \\
\hline $\mathrm{C} 1 \mathrm{aC} 2 \mathrm{i}(\mathrm{C} 3)$ & $\begin{array}{l}\text { majik' 'right-handed, } \\
\text { downright' }\end{array}$ & mijak ${ }^{W}$ 'be dextrous' \\
\hline $\mathrm{C} 1 \mathrm{a}: \mathrm{C} 2 \mathrm{i}(\mathrm{C} 3)$ & $\begin{array}{l}\text { sagi 'distant' } \\
\text { na:si 'advisory' } \\
\text { na:k }{ }^{W} \text { is 'short' }\end{array}$ & $\begin{array}{l}\text { sig 'be distant' } \\
\text { nasa 'advice' } \\
\text { nik"is 'be short' }\end{array}$ \\
\hline $\mathrm{C} 1 \mathrm{aC} 2 \mathrm{a}: \mathrm{C} 3$ & $\begin{array}{l}t^{t a k^{W} a} a k^{W} \text { 'prepared, ready, } \\
\text { finished, }\end{array}$ & $t i k^{W} i k^{w}$ 'prepare' \\
\hline $\mathrm{C} 1 \mathrm{iC} 2 \mathrm{a}: \mathrm{C} 3$ & Sik a:n 'aromatic' & $\begin{array}{l}\int i k^{W} \text { an 'emit pleasant } \\
\text { odour, perfume oneself' }\end{array}$ \\
\hline $\mathrm{C} 1 \mathrm{aC} 2 \mathrm{C} 2 \mathrm{iC} 3$ & Jallik'few' & Silik'be few' \\
\hline
\end{tabular}
from verbs. All are based on a qualitative vocalic alternation, in a few cases with the addition of a suffix - $a$. Arabic has no dedicated adjectival patterns (but the active participle pattern of the verbal base form C1a:C2iC3 may correspond to adjectives), and Afar and Saho do not have an adjectival category.

Table 3: Adjective patterns 
The last pattern with a geminated second consonant is most probably a fossilized form.

\subsubsection{Nouns}

There are eleven different patterns with qualitative ablaut for nouns related to the old prefix verb form V2, of which two (C1aC2i and C1iC2i) are shared with the adjectival patterns. In addition, two patterns can have a suffix -a. Most of the patterns of tri-consonantal roots are common with Arabic, not surprisingly considering the small number of vowels in each language.

\begin{tabular}{|c|c|c|}
\hline Pattern & Adjective & Verb form \\
\hline C1aC2 & $n a k^{W}$ 'pregnancy' & $n i k^{N} i$ 'become pregnant' \\
\hline C1iC2a & nisa 'advise, counsel' & nasa 'advice' \\
\hline $\mathrm{C} 1 \mathrm{aC} 2 \mathrm{i}$ & sari ‘wakefulness’ & sir 'keep awake' \\
\hline $\mathrm{C} 1 \mathrm{aC} 2 \mathrm{a}$ & $\begin{array}{l}\text { nada'dew' } \\
\text { sala 'roast meat' }\end{array}$ & $\begin{array}{l}\text { nidaj 'sweat, exude water' } \\
\text { asal 'roast, fry' }\end{array}$ \\
\hline C1iC2i(C3) & $\begin{array}{l}\text { mir?i 'width' } \\
\text { rifid 'wealth' }\end{array}$ & $\begin{array}{l}\text { mir? 'be 'wide' } \\
\text { rifid 'raise, attend to, care } \\
\text { for cultivation or cattle' }\end{array}$ \\
\hline $\mathrm{C} 1 \mathrm{aC} 2 \mathrm{i}: \mathrm{C} 3$ & $\begin{array}{l}\text { Jadi:d'strip (of bark)' } \\
\text { fak' lin 'fragrance' }\end{array}$ & $\begin{array}{l}\text { Jidid 'strip off' } \\
\text { Jik an 'emit pleasant odour, } \\
\text { perfume oneself' }\end{array}$ \\
\hline $\mathrm{C} 1 \mathrm{aC} 2 \mathrm{i}: \mathrm{C} 3-\mathrm{a}$ & rasird-a 'cattle' & $\begin{array}{l}\text { rifid 'raise, attend to, care } \\
\text { for cultivation or cattle' }\end{array}$ \\
\hline $\mathrm{C} 1 \mathrm{i}: \mathrm{C} 2 \mathrm{a}: \mathrm{C} 3$ & $\begin{array}{l}\text { safi:f-a (f) ‘splice’ } \\
\text { ti:la:l 'stride' }\end{array}$ & $\begin{array}{l}\text { sifif'splice (us. rope)’ } \\
\text { tilil ‘stride, be, go far away } \\
\text { from home' }\end{array}$ \\
\hline C1uC2uC3 & sukum 'colostrum' & $\begin{array}{l}\text { sik }^{w} i m \text { 'to draw off thick } \\
\text { milk from parturient animal' }\end{array}$ \\
\hline C1aC2o:C3 & tabo:k 'double-handful' & $\begin{array}{l}\text { tibo:k'fill scoop with } \\
\text { cupped hands' }\end{array}$ \\
\hline C1iC2u:C3-a & tilu:l-a ‘exile’ & $\begin{array}{l}\text { tilil 'to stride, be, go far } \\
\text { away from home' }\end{array}$ \\
\hline
\end{tabular}

Table 4: Noun patterns

\subsubsection{Instrument nouns}

There are a few instrument nouns whose pattern is made with qualitative ablaut and a prefix $m$-, like in Arabic, where, contrary to Beja, this prefixed pattern is frequent and productive. But note that the Beja instrument nouns do not seem to be borrowings from Arabic. In one instance C2 is reduplicated. Another pattern consists of a suffix -an (which does not belong to the patterns of instrument nouns in Arabic), in addition to the ablaut. They seem to be frozen forms in Beja. 
(9) Instrument nouns of V2

himi 'cover' > m-himme:j 'blanket'

Pafi 'prevent, secure' > m-Pafaj 'nail, rivet, fastener'

min 'shave' man-an 'razor'

Afar and Saho also have some instrument nouns following a similar pattern (see SIMEONE-SENELLE \& VANHOVE 2006: 44).

\subsubsection{Place nouns}

A few place nouns are also based on the pattern with the ablaut and the prefix $m V$-. While this is a frequent and productive category in Arabic, it is a frozen one in Beja.

(10) Place nouns of V2

ginif'kneel' > mi-gnaf'camp'

ridif'set on a pillion (sp. on camel)' > mi-rdaf'rump'

mo:k 'take shelter' > ma- $k^{w} a$ 'place of shelter'.

Afar and Saho also have some place nouns following a similar pattern (see SIMEONE-SENELLE \& VANHOVE 2006: 44$)^{6}$.

\subsubsection{Plural patterns}

The so-called 'broken plural' patterns are common and frequent in the South-Semitic languages of North-East Africa and in Arabic. Beja (as Afar and Saho) also has a limited set of broken plural patterns, but it developed its own system which is partly predictable. Ablaut patterns for plural formation mainly concern non-derived nouns either containing a long vowel, or ending in a diphthong. Whatever the number of root consonants and the syllabic structure, both long $i$ r and $u r$ in the singular turn into short $i$ in the plural, and long $a r, e r$ and $o r$ turn to short $a$, sometimes with the addition of the plural suffix $-a$ for the former. Nouns ending in -aj turn to a long vowel - e:j.

(12) Plural patterns

ang $i: l$, pl. $a n g^{w} i l$ 'ear'

lu:l, pl. lil 'rope'

asu:l, pl. asil 'blister'

hasa:l, pl. hasal/ hasal-a 'bridle'

me:k, pl. mak 'donkey'

bo:k, pl. bak 'he-goat'

ganaj, pl. gane:j 'gazelle'

6 The semantics of some Beja words following the patterns with the $m V$ - prefix may be different and not predictable: rifif 'drag an object along the ground' > mi-rfaf'reptile'; mafsa 'hair swept to the sides of the face' $>$ mi- $\int u$ : $f i$ 'spinster' (married women wear a fringe on the forehead, or plaits). 
Some old and recent borrowings from Arabic also conform to these patterns:

(13) Plural patterns of borrowings

ka:m, pl. kam 'camel' (Arabic gama)

ba:buir, pl. ba:bir 'steamer' (pl. in Sudanese Arabic is bawa:birt)

Reduplication of the beginning of the first syllable together with ablaut is rare and limited to adjectives:

(14) Plural patterns of adjectives

win, pl. waiwin 'big'

dis, pl. da:dis 'small'

Prosody is also employed in Beja, with a change of stress assignment to mark plurals in a few nouns:

(15) Plural patterns with stress shift

hadái-b 'a lion', pl. hádai- $b$.

Even though broken plurals can be considered as a genetic feature, the fact that they are very rare or absent in other Cushitic languages (Zaborski 1986) speaks for a possible influence of Semitic upon Beja (and Afar and Saho).

\section{Conclusion}

Although Beja and Arabic share a typologically similar morphological system based on the root and pattern schema, the above overview has shown that each language has developed its own system, both in terms of semantics and forms. In this morphological domain, although these languages have been in contact for centuries, neither small scale nor massive borrowing from Arabic morphological patterns can be postulated from the Beja data.

Although it has not been possible within the limits of this paper to make a thorough comparison with Afar and Saho, the two other Cushitic languages in which the root and pattern morphology is not marginal or absent, it is nevertheless important to emphasize that this morphological type is less developed in these two languages. In particular, vocalic alternation is not used in their verbal derivation systems and is restricted in the conjugation paradigms to only $30 \%$ of the verbs as opposed to $60 \%$ in Beja.

Three characteristics of these languages deserve our attention. Firstly, the morphological systems of other Cushitic languages are predominantly or, most often, exclusively concatenative. Secondly, the root and pattern schema is less developed in neighboring Afar and Saho for which contact with Arabic has been less pervasive. Thirdly, Arabic is the dominant and prestigious language for the Beja speakers, even though very few of them 
have entirely shifted to Arabic. If one admits the hypothesis that the root and pattern morphological system is inherited in both languages, given these three characteristics, it is tempting to think that contact with Arabic was a strong factor for the preservation of this system in a large part of the Beja morphology and that we have here a case of convergence.

Thus, it seems that intensive language contact does not only lead to morphological borrowings, copying, replication, etc., as is generally discussed in the literature on language contact, but may help to preserve a morphological system in genetically related languages which otherwise would have disappeared as is the case in most other Cushitic languages. Beja morphology would not show a case of contact-induced change, but a case of contact-induced preservation. A situation particularly tricky to disentangle if one keeps in mind that "if genetically related languages are in contact, trying to prove that a shared feature is contact induced and not a 'chance' result of Sapir's drift may be next to impossible” (Aikhenvald 2007: 9), let alone if it is not a matter of change, but a matter of preservation of a proto-system, not in every single detail of course, but as an overall picture. This study is meant as a first step towards a more comprehensive and in-depth research.

\section{Abbreviations}

$\begin{array}{ll}\text { CAUS Causative } & \text { RECP Reciprocal } \\ \text { FREQ Frequentative } & \text { REFL Reflexive } \\ \text { INT Intensive } & \text { sp. Specially } \\ \text { IPFV Imperfective } & \text { TAM Tense, Aspect, Mood } \\ \text { MSA Modern South Arabian languages } & \text { us. Usually } \\ \text { PASS Passive } & \text { V1 Verb class 1 (with suffixes) } \\ \text { PFV Perfective } & \text { V2 Verb class 2 (with prefixes) } \\ \text { pl. Plural } & \end{array}$

\section{References}

Aikhenvald, AleXandra Y. (2007): Grammars in contact. A cross-linguistic perspective, in: Aikhenvald, A.Y. \& Dixon, R.M.W. (eds.), Grammars in contact. A crosslinguistic typology. Oxford: Oxford University Press, 1-66.

Blachere, Regis \& Gaudefroy-Demombynes, Maurice (1975, $3^{\mathrm{e}}$ ed.): Grammaire de l'arabe classique. Paris: Maisonneuve et Larose.

CoHen, DAvid (1969-70): L'inaccompli en -n- du bédja et le système verbal chamitosémitique, in: Comptes Rendus du G.L.E.C.S. XIV, 69-75.

COHEN, DAVID (1974): Alternances vocaliques dans le système verbal couchitique et chamito-sémitique, in: Caquot, A. \&. Cohen, D. (eds.), Actes du ler Congrès international de linguistique sémitique et chamito-sémitique. Paris, 16-19 juillet 1969. La Haye/Paris: Mouton, 40-48.

COHEN, DAVID (1984): La phrase nominale et l'évolution du système verbal en sémitique. Etude de syntaxe historique. Leuven/Paris: Peeters. 
CoHen, David (1988): Couhitique-Omotique, in: Les langues dans le monde ancien et moderne. Langues chamito-sémitiques, Cohen, D. (ed.). Paris: Editions du CNRS, 243269.

Crass, Joachim \& Meyer, Ronny (2007): Ethiopia, in: Heine, B. \& NurSe, D. (eds.), $A$ linguistic geography of Africa. Cambridge: Cambridge University Press, 228-250.

FERGUSON, CHARLES (1970): The Ethiopian language area, in: Journal of Ethiopian Studies 8/2, 67-80.

FERguson, Charles (1976): The Ethiopian language area, in: Bender, L., Bowen, D., CoOper, R. \& Ferguson, C. (eds.), Language in Ethiopia. London: Oxford University Press, 63-76.

HETZRON, ROBERT (1977): The Gunnän-Gurage languages. Napoli: Istituto Orientale di Napoli.

Leslau, Wolf (1945): The influence of Cushitic on the Semitic languages of Ethiopia: A problem of substratum. Word 1, 59-82.

LESLAU, Wolf (1952): The influence of Sidamo on the Ethiopic languages of Gurage. Language 28/1, 63-81.

LeSLAU, Wolf (1959): Sidamo features in South Ethiopic phonology. Journal of the American Oriental Society 79, 1-7.

LESLAU, WOLF (2000): Introductory grammar of Amharic. Wiesbaden: Harrassowitz.

RAZ, SHLOMO (1983): Tigré grammar and texts. Malibu, Undena Publications.

ROPER, E.M. (1928): "Tu Bedawie”. An elementary handbook for the use of Sudan government officials. London: Austin.

SASSE, HANS-HÜRGEN (1986): A southwest Ethiopian language area and its cultural background, in: Fishman, J.A., Tabouret-Keller, A., Clyne, M., Krishnamurti B. \& Abdulaziz, M. (eds.), The fergusonian impact: In honor of Charles A. Ferguson on the occasion of his 65th birthday. Berlin: Mouton de Gruyter, 327-342.

Simeone-Senelle, Marie-Claude \& Vanhove, Martine. 2006. Is there a Red Sea linguistic area?, in: APAL (Annual Publication in African Linguistics) 4, 31-67.

THOMASON, SARAH G. \& KAUFMANN, TERRENCE (1988): Language contact, creolization, and genetic linguistics. Berkeley/Los Angeles/London: University of California Press.

Tosco, Mauro (2000): Is there an 'Ethiopian language area'?, in: Anthropological Linguistics 42/3, 329-365.

Ullendorf, Edward (1955): The Semitic languages of Ethiopia: A comparative phonology. London: Taylor's.

ZABORSKI, ANDRZEJ (1986): The morphology of nominal plural in the Cushitic languages. Wien: Beiträge zur Afrikanistik, vol. 28.

ZABORSKI, ANDRZEJ (1991): Ethiopian language subareas, in: PILASZEWICZ, S. \& RzewUSKI, E. (eds.), Unwritten Testimonies of the African Past. Warsaw: Wydawnictwa Uniwersytetu Warszawskiego, 123-134.

ZABORSKI, ANDRZEJ (2003): Ethiopian language macroarea. Sprawozdania z posiedzeń komisji naukowych 45/2, 60-64.

Author's address:

Martine Vanhove

LLACAN - CNRS

Centre André-Georges Haudricourt

7, rue Guy Môquet - BP 8

94801 Villejuif cedex

FRANCE

vanhove@vjf.cnrs.fr 